$\mathbb{T}$ periodica polytechnica

\author{
Architecture \\ 43/1(2012) 37-44 \\ doi:10.3311/PPar.7159 \\ http://www.periodicapolytechnica.org/ar \\ Creative Commons Attribution (i) \\ RESEARCH ARTICLE \\ Martin Pilsitz \\ RECEIVED 2013-06-28
}

\section{On the Industrial} Urban Development of Pest in the 19th Century

\begin{abstract}
As the point of departure for industrialization and the development of a separate architecture for factories, the Industrial Revolution has been seen as an all-encompassing concept-one that explains the industrialization process that spread gradually from Great Britain to the continent [19]. Although this viewpoint is not erroneous from a pan-European perspective, it does not give us the full picture [17]. Since the process of industrial urban development was not uniform in the various industrial centres, in order to gain an accurate and undistorted impression of industrial urban development in, for example, Budapest, we need to examine the subject matter from a "regional perspective" [11]. The article focuses on the regional aspects of industrial development in urban Pest, with special consideration to the engineering and brewing industries.
\end{abstract}

\section{Keywords}

Industrial urban development in Budapest $\cdot$ research on industrial construction in Budapest $\cdot$ cellar systems in Köbánya . Brauerei Mayerffy $\cdot$ Brauerei Barber-Klusemann

\section{Martin Pilsitz}

Department of History of Architecture and of Monuments,

Faculty of Architecture, Budapest University of Technology and Economics 1111 Budapest, Mủegyetem rakpart 3. Hungary

email: pilsitz.martin@gmail.com

\section{Spatial and structural requirements as the basis for the development of industrial sites in Pest}

While the suitability of a site for agriculture depends primarily on natural conditions, such as the presence of sufficient water and good soil quality, it is infrastructure (created through planning and work) that determines the choice of location for business and industry. Since, in most cases, insufficient capital is available for the uniform distribution of infrastructure around the country, highly productive economic activities tend to be concentrated in urban locations. The spatial concentration of infrastructure creates additional cumulative effects that enhance this process. As a direct consequence, certain locations can become more attractive, a process which can be enhanced or weakened through economic measures and technological developments. In the case of Budapest, we see that the city developed into an important industrial centre in the second half of the 19th century, despite the absence of raw mineral materials in the region, which might have served as a foundation for industrial production. However, in Budapest, a number of beneficial factors essential for industrial development compensated for this competitive disadvantage [2].

One of these conditions was Budapest's central position within the transport network of the Austro-Hungarian Empire, coupled with its location on the Danube. The city was connected via the Danube waterway with the agricultural production centres to the south and such major European cities as Vienna to the north and west. The function of the Danube as a transport route is shown by the presence of warehouses, toll stations and market halls along the riverbank in Pest. Following the advent of the railways in 1846, a nationwide transport system capable of meeting the needs of industry was established; the network was completed by the turn of the century. The upgrading of the transport network was a prerequisite for the development of large companies and the concentration of industry. Other factors were a favourable labour market and the city's role as a political and cultural centre.

The quantitative dominance of the agricultural sector in Hungary, combined with the aforementioned situational features, 
led initially to the emergence of the food industry in Budapest. From 1860, however, the arrival of the railway spurred development in other industrial sectors, such as machinery and machine tools. This was the beginning of a process whereby machinery and engineering became Budapest's principal industry. Major factories operating in the railway/engineering sector were:

- Láng László Gépgyár, founded in 1868

- MÁV Gépgyár, 1873

- Dr. Födessy, later became Unio Gépgyár, 1895

- Tarnóczy Rt., 1889

- Zoltán Győző Gépgyár

- Oetl Gépgyár és Vasöntőde

- Langfelder Gépgyár,1890, and subsequently Herkules

- Rothschild Gépgyár [1]

Unlike in the textile industry, ${ }^{1}$ where unskilled workers could be employed, in the engineering sector (and particularly in the machine tools industry) skilled workers were required in order to make tools based on technical drawings and assemble machines [15]. They thus required the relevant technical knowledge. Consequently, in addition to the existing technical colleges, industrial schools were established for the training of skilled workers and technicians. In this way, a large number of skilled workers entered the labour market. In the late 19th century, as a consequence of a process of dynamic development, an independent electrical engineering sector arose. From 1880, onwards, the chemicals industry became increasingly important.

As a consequence of this development, by the turn of the century, Budapest had become the country's main industrial centre. The industries referred to, were labour and employment intensive. The urban area of Pest-Buda - as the country's cultural, economic and political centre - attracted people from all around the country. Accordingly, the city's population grew rapidly:

\begin{tabular}{ll} 
Year & Population of Pest-Buda (or Budapest, from 1873) \\
\hline 1848 & 110,516 \\
\hline 1851 & 178,016 \\
\hline 1869 & 280,349 \\
\hline 1873 & 296,867 \\
\hline 1880 & 509,384 \\
\hline 1900 & 733,358 \\
\hline 1910 & $880,371[16]$ \\
\hline
\end{tabular}

\section{Industrial centres arising due to the migration of industry from the city centre to the outskirts}

In the mid-19th century, residential and industrial areas were closely integrated in the city. Production companies in the manufacturing industry caused damage to the environment through

1 The textile industry in Budapest played a lesser role. pollution (noise and emissions). The mostly small businesses did not have the room to expand. With the construction of a mass transit system, it was possible to separate residential and industrial areas. This resulted in concentrations of industrial sites on the edge of the city, especially in the metal processing and engineering sectors [12]. The locations of the industrial areas (especially the axes of development along Váci Street and Soroksári Street) were directly linked with the development of mass transportation. Transport speed and mobility costs ("Speed" and "fares", i.e. time and money) are the two main determinants of the means of transport and thus of spatial and settlement patterns. To minimize the amount of time for the receipt and delivery of energy, raw materials and finished products, an industrial railway system was established in Budapest. Overall, the outsourcing of production from the city centre and the establishment of industrial zones led to a further concentration of infrastructure within the city. At the same time, these developments also resulted in additional cumulative effects synergies - which spurred industrial development. Owing to their significant structural dimensions and characteristic facades, manufacturing plants with a lasting visual impact on the environment emerged [25].

\section{The significance of the historical brewing houses for industrial development in urban Pest in the 19th century}

Following the overview of the topic, it is important to address the significance of historical brewing houses for the industrial development of Pest in the 19th century. The starting point is that, as early as the first half of the 19th century, this branch of industry was providing an impulse for the emergence of regional industrial areas - areas that have not previously been a priority topic for urbanization researchers. At the same time, the consequences of developments in the metal-working industry on other industries should be examined.

\section{Impulse No. 1 - The diametrical endpoints of the distribution of breweries in the Pest urban area become starting points for further industrial city development}

In 1815, the sites of the two newly established breweries, Mayerffy and Petz, were at the diametrical extremities of the area in which breweries were located in Pest [21]. The building of the new plants and their location outside the medieval city walls was due to the risk of fire associated with the old commercial buildings (fires in the Tabán and Víziváros districts in 1810) [27]. In the ensuing period, these two sites became the geographical starting points for industrial development along Váci Street and Soroksári Street [5]. Both roads run parallel to the Danube and represent the southern and northern axes and supply routes between Budapest and the countryside. Geometrically, the development occurred along axes running away from 


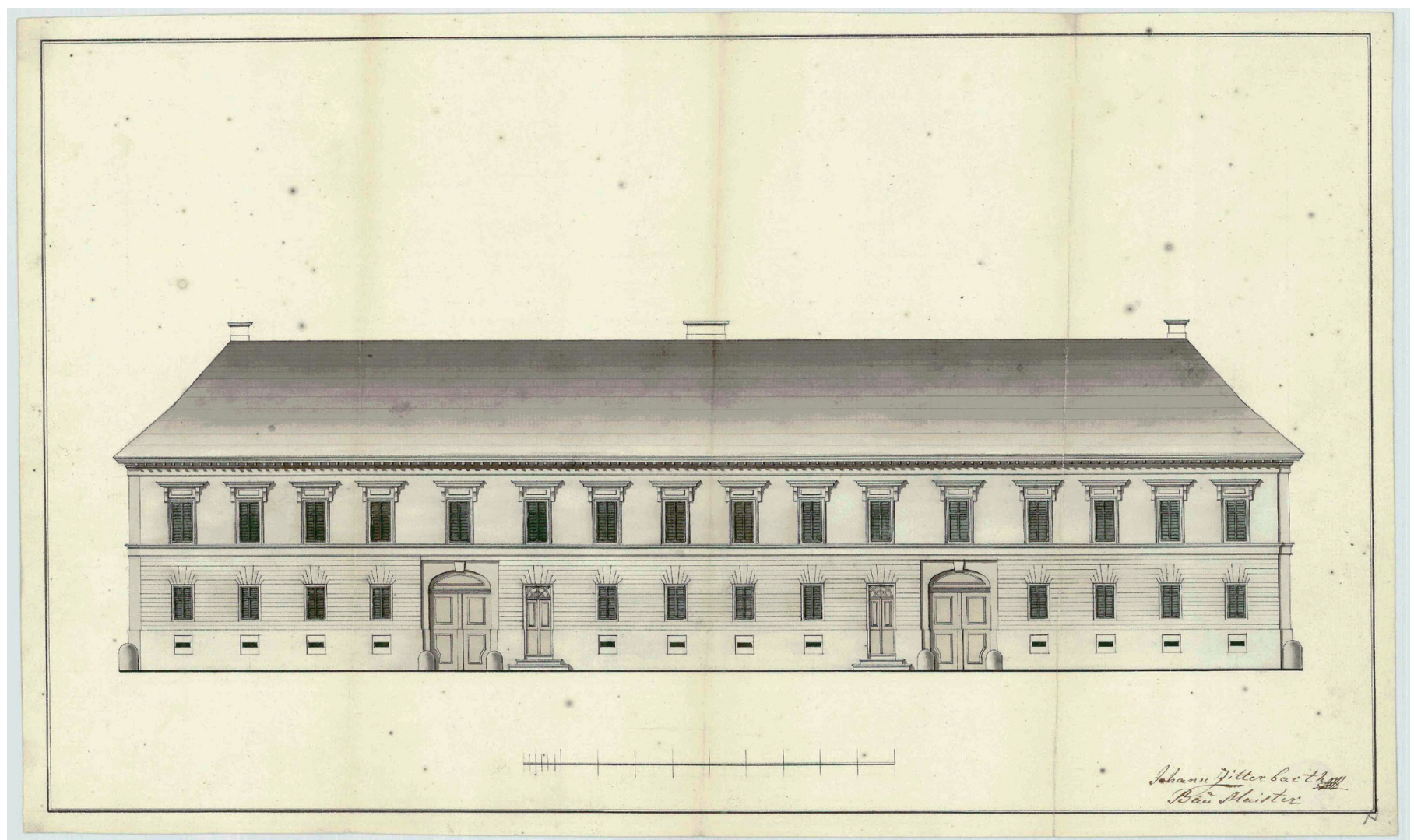

Fig. 1. Mayerffy Brewery, Budapest, 1815 (Source: Budapest Főváros Levéltár 15.17.b.311 szb 01393c)

the city centre. The trigger for this process was the railroad. The opening of the first railway line in 1846 set in motion a dynamic interaction between infrastructure investment and access to European markets [20]. As described above, the principal beneficiary was the engineering sector, with a large number of factories being built along the development axes.

\section{Impulse No. 2 - The migration of industry to the outskirts}

Around 1850, the early industrial breweries migrated from the centre of Pest to Köbánya, at the edge of the settlement area. Geometrically, these developments took place unilaterally. The brewing sector's migration to the outskirts constituted a second impulse for subsequent industrial development in $\mathrm{Bu}-$ dapest. The causes and motives of this migration are mentioned in the section Impulses for moving sites.

Compared with the breweries, other important industrial sectors, such as the metal-processing industry, left the city centre for the suburbs somewhat later - from 1880 onwards. Causes for the migration of industry away from the city centre were problems stemming from the interdependence between

2 An exemplary plant is Pick Ede Gépgyára. Ede Pick established his locksmith workshop in Budapest's sixth district in 1879. It seems the company then moved to Külső Váci Street no. 40 around 1890, where by 1898 it had 100 workers producing machinery and tools for the manufacturing industry. workshops and residential development; in most cases, such problems precluded an expansion of the plant. In contrast, the migration to the suburbs allowed some metal-processing companies to become true engineering plants. The peripheral areas had the following advantages as a business location:

- Free of dense residential development

- Not part of established city layout

- Land at low prices

- Expansion possible, in view of reserves of land

- Production with high emissions was possible (e.g. iron foundry)

- Railway connection

- The Danube could serve as a source of water for the plant; it also represented a natural limit for industrial area

A prerequisite for the migration of large engineering companies with a high number of workers (e.g. Láng Gépgyár, Váci út 152-158: 430 workers in 1898; Első Magyar Gazdasági Gépgyár, Váci út 19: 900 workers in 1896; Fegyver és Gépgyár, Soroksári út 100: 450 workers) [3] was the development of a public transport network. The emergence of this network rendered areas to the north and south of the city centre (along Váci Street and along Soroksári Street) [12] suitable for industrial development. Both axes of development conveniently ran next to the Danube (a waterway), and there were good railway links. ${ }^{2}$ The Weiss Company played an important role in 
the development of the southern axis along Soroksári Street. Originally conceived as a canning factory, the company's plant began producing munitions in 1886 . Due to this diversification and the associated risks of explosion, the company moved to Csepel Island, a largely undeveloped area, in 1892. The change in site served as a catalyst for the emergence of a major industrial area with its own history. Csepel Island's industrial development should not be understood merely as an appendix to the developments on Soroksári Street.

After this migration to the periphery, the spatial movement of industry in Budapest came to a standstill. In the subsequent period, the new industrial sites were developed and expanded, but not fundamentally altered.

\section{The connection between design and location determines the effect of industrial construction on the city outskirts}

The migration of industry from the city centre to the urban periphery meant the removal of production facilities from the built-up environment of the centre to the undeveloped area of the periphery. This change increased the importance of the individual structures of buildings. Indeed, the design of a freestanding building necessarily evoked a different visual effect - to that of buildings in the urban centre - in view of the space available. The striking contrast between the constructed (manmade) industrial buildings and the surrounding landscape was enhanced by the dimensions of the buildings, which became larger over time and thus came to dominate the landscape. Regarding the design of the factory buildings, simple geometric forms were used, resulting in simpler facades.

At the same time, the appearance of the production sites was increasingly determined by technical factors and elements, which are still visible on the facade. The industrial chimneys and large ventilation ducts required new construction concepts: their great height meant that they were not integrated into the building, but were placed next to it. In view of their dimen- sions, they could no longer be subordinated architectural components. Rather, to ensure stability, they required an elaborate design and careful construction. The industrial chimneys are indirect indications of the application of advanced combustion technology and the use of steam engines for power generation.

The link between location and design marks the beginning of "technicist" architecture, which gradually became typical in the construction of both industrial buildings and commercial buildings, including barracks and stations.

\section{The effect of the migration of industrial sites on urban development and building legislation in Budapest}

The migration of industry to the city's outskirts significantly affected Budapest's urban development, and yet until 1870, this process was not subject to urban planning regulations [18]. The available urban planning plans were generally regulative in nature; they contained very little other than marking out routes for the construction of roads (and the width of such roads). However, in the last three decades of the 19th century, the concentration of industrial sites in a particular area and the resulting movement of workers between their homes and their workplaces necessitated the adoption of a statutory provision in order to resolve the problem of "living and working in different places".

Planning laws were then enacted and developmental issues were regulated. Act X of 1870 assigned Budapest's Public Works Council the task of elaborating a "proposal for the regulation of building construction" [24]. This is the reason for the interaction between urban development and industrialization, which still continues to exert an effect on Budapest [4]. Even street names refer to former industries or companies: for example in District IX: Fegyvergyár utca; in District VIII: Csavargyár utca; and in District X: Sörgyár utca.

\begin{tabular}{ll}
1844 Schmidt Péter & Location: Üllöi út 31. Use of cellar for aging and storage purposes Storage cellar \\
\hline 1845 Tüköry & $\begin{array}{l}\text { Location: Szent István körút. Site bordered by Katona Jószef utca, Hollán utca and Pozsonyi utca } \\
\text { Use of cellar for aging and storage purposes }\end{array}$ \\
\hline 1850 (?) Brauhaus Carl Rohrbacher & Brewery (Serfözöház) \\
\hline 1854 Barber és Klusemann & Brewery (Serfözöház) \\
\hline 1855 Köbányai Serház Társaság & Brewery \\
\hline 1860 & Construction of a new brewery \\
\hline 1859 Dreher & Purchases of plots \\
\hline 1862 Dreher & Takeover of new brewery belonging to Köbányai Serház Társaság \\
\hline 1892 Polső Magyar Részvény Serfözde Rt. & Barber and Klusemann is incorporated \\
\hline 1893 & Foundation of the brewery, purchase of plots \\
\hline $1894 / 95$ Király Serfözde & Brewery and malthouse \\
\hline 1908 Haggenmacher & Brewery \\
\hline 1913 Fövárosi Serfözde Rt. & Brewery \\
\hline
\end{tabular}

Tab. 1. By 1862, the following breweries had been established in the area 


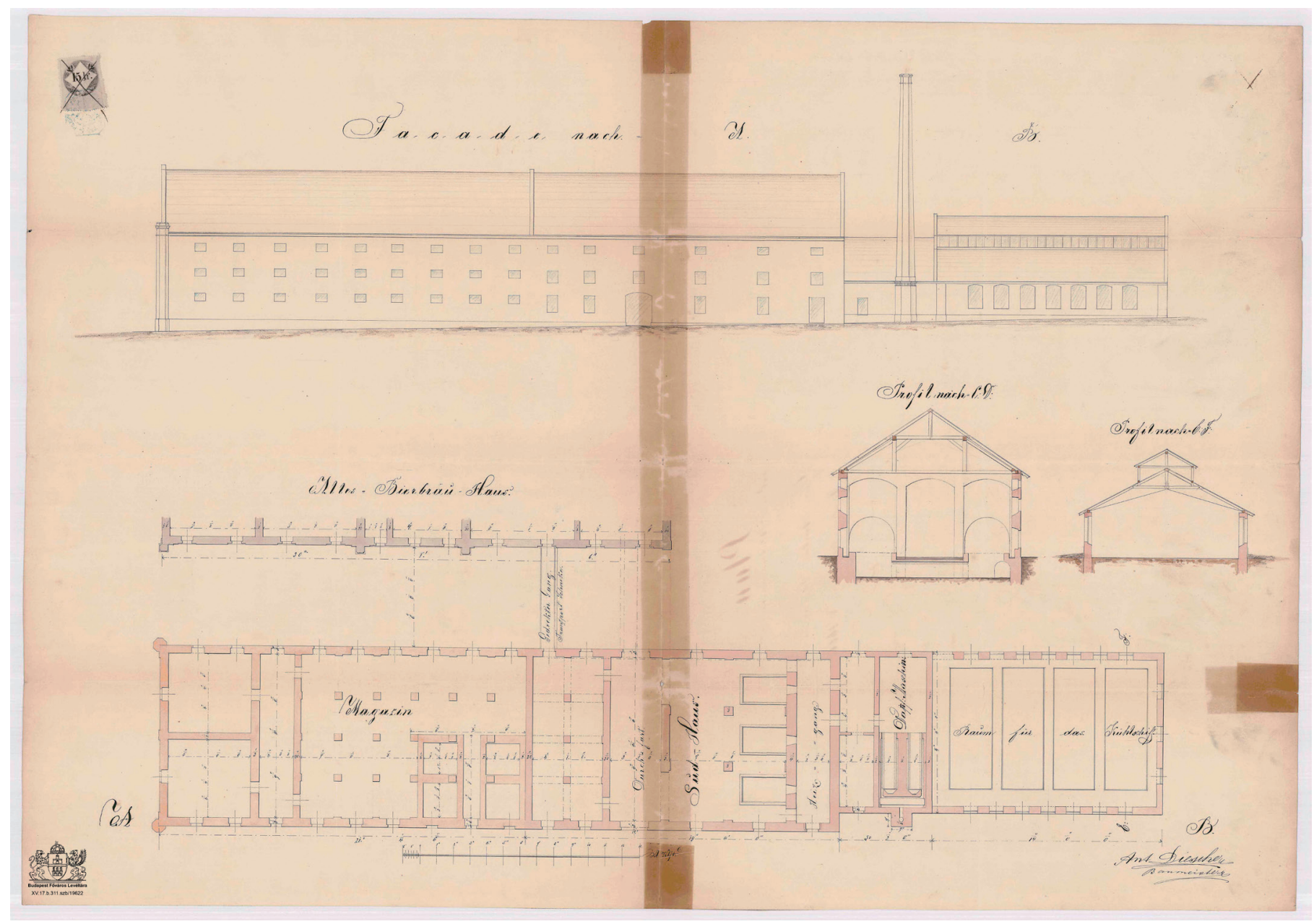

Fig. 2. Barber Klusemann Brewery, Budapest, 1854 (Source: Budapest Főváros Levéltár 15.17.b.311 szb 19622)

\section{Factors (impulses) triggering a change in location}

The main location of the early industrial breweries in Köbánya was a nearly square-shaped construction area. The area lay in the north-west, on the edge of the settlement area. It was bordered to the north by a railway line and to the west by a residential development. There was access to the railway tracks and to Köbánya Felső Pályaudvar. To the south lay vacant plots along and to the east of today's Maglódi Street. As time passed, they were used for the establishment of new breweries or the expansion of existing breweries.

Factors (grouped according to the degree of correlation with location) leading to the migration of the brewing industry from the city centre of Pest to Köbánya (and later to Budafok):

\section{A. No correlation}

Technical innovations

B. Moderate correlation

Raw materials

Labour

C. High correlation

Topography and geology

Site (plot)

\section{A. Technical innovations Deep drilling techniques provide access to water for brewing}

From 1840, it was technically possible (by means of artesian drilling) ${ }^{3}$ to create wells and thus gain access to water for brewing. Consequently, breweries in Pest-Buda no longer had to be situated near the Danube and the benefits of other locations could be utilised. ${ }^{4}$ In Köbánya, there were ample supplies of such water and the quality was adequate.

\section{B. Raw materials and labour}

In the surrounds of Köbánya, there were major hop-growing areas: Duplamező, Város-Retje, Nevelö földek. As a result the transportation routes for this raw material and the associated costs were minimized. Thus, the choice of location of the breweries follows the classic pattern of industrial development: to settle in an area where raw materials and/or energy sources are available.

3 Vilmos Zsigmondy, a trailblazer in Hungary in the field of drilling artesian wells, developed numerous solutions for exploiting the thermal water reserves to be found under City Park [Városliget] and Margaret Island [Margitsziget].

4 Around 1850, all breweries in London had their own artesian wells. 
A labour market with well-trained workers (guild-trained), who were familiar with the highly specialised operation of a brewery, was a further advantage of the location. In the brewing industry, large production volumes could be achieved with relatively few skilled workers. The workers were usually housed on the premises. Therefore, unlike the engineering industry, the development of the breweries was not linked to the development of a public transport network. This explains why the brewing industry became industrialised relatively early on.

\section{Topography and geological conditions The cellar system as a spatial aspect of brewing}

The production process of "bottom-fermented" beer required storerooms, where the beer could mature for six months at a low temperature and constant humidity. Creating large storage spaces such as cellar buildings, using masonry construction techniques, was technically possible but very costly. A cheaper option was to use existing cellar systems, such as those in Köbánya, which had been created during the underground mining of limestone. The tunnel-like cavities provided ideal climatic conditions and could be redesigned to meet the needs of a brewery in a short time and at low cost. Concerning the origins of the system of cellars, the Borsodi-Bevillág wrote the following: "Initially, vineyards were established in Köbánya and the cellars were needed for storage. For this, natural caverns were walled off at the sides, forming separate cellars. The uniform temperature and humidity had a positive impact on the maturing process of the wine. Around the middle of the 19th century, some less well-off families used the cellars for housing."[7]. On the same theme, János Lukács wrote: "In 1244, Béla IV gave the town of Köbánya to [the municipality of] Pest. The documents for the area contain such names as Kewerfelde, Kuerfelde, Küer, and Köér. The former Köérfölde with its soft sandstone proved suitable for mining. The mining did not take place in open pits; rather, there were long corridors from which large blocks were cut. The result, after some centuries, was the system of cellars in Köbánya, with its typical long corridors. The soft sandstone could be both trimmed and cut. During raids by the Tatars, the wooden houses of the people were set on fire. Thereafter, houses were built using stone. The direct benefits of extracting the stone were:

1. The material produced was of value itself.

2. The caves thus created could be used as wine cellars.

The caves were dry, and so poorer families made dwellings for themselves there.

The extracted material was used in the construction of public buildings: the Hungarian Academy of Sciences, St Stephen's Cathedral (basilica), the facade of the tunnel, the upper part of the columns of the Chain Bridge and the four lions. The hilly terrain was suitable for wine growing and therefore constituted a value in itself, which is why the material was mined under- ground. Thus, a fundamental link was established between the production of wine and an artificial geological formation." [14]

\section{Geology}

Köbánya and the surrounding area lie on Pannonian stratified Sarmatian limestone (coarse limestone).

In terms of the inner and outer forms, the area is identical to the Nagytétény plateau. At the northern end of Budafok near the Köéer Stream-brook, there are the former Sörház utca (later on Csap utca) plots, with small but very characteristic terraced fields covered in pebbles. This pebble area is really a rock terrace on the fine sand and sandy clay of the so-called Pannonian floor. These Pannonian surfaces are layered in the same way as the areas lying on the Sarmatian limestone of Köbánya and the surrounding areas [6].

\section{Plots}

At the beginning of the 19th century, the plots of land that would later become sites for large breweries were owned by private individuals. Thus, land ownership in Köbánya differed fundamentally from land ownership in the inner city, where the breweries were required to lease land for fixed periods of time from the municipality.

Borsodi-Bevillág mentioned the following owners: [8]

- Mihály Rumpellesz, who owned plots which became Site V, Site IV and Site VII.

- Frigyes Feszl (Architect), owner of a whole series of plots.

- Hoffhauser and Feszl, joint owners of the site of the brick factory.

- Orbán Lechner (master brewer), who owned the "Double Meadow" (dupla-mezö) and rented some arable land in the area.

\section{Urban structures are established at the industrial sites}

Private initiative resulted in the relocation of the production and the establishment of new breweries. This process was the result of decisions taken by brewery owners based on business and economic considerations. The construction records of construction companies show that construction and alteration projects were a permanent feature at these industrial sites. The projects were structurally complex and resulted in urban structures: at these sites, infrastructure (industrial rail sidings, road links, and street construction), social facilities (canteens, bathrooms and other facilities) and energy production facilities (boiler and engine rooms) were integrated, resulting in structures that were reminiscent of urban structures.

\section{Natural landscapes, cultural landscapes, industrial landscapes and renaturalised landscapes. Köbánya: the transformation of an agricultural landscape into an industrial landscape}

In the industrial migration to the outskirts described above, we see a process in which the landscape is taken over by 
industry. The treatment of the suburban landscape reflected in principle the notion of landscape as it was perceived at the time and, by extension, that of the world. From this context, one can deduce several basic considerations with regard to the importance of the industrial migration to the outskirts.

With the migration to the outskirts (to Köbánya), the brewing industry entered a wine-growing area, thereby transforming an agrarian cultural landscape into an industrial landscape. Extensive land use was replaced by intensive land use, whereby the visible aspects of industrialization (factory buildings and infrastructure) became determinative and formative factors of the landscape. At the same time, this phenomenon exemplifies the practice of converting land for industrial purposes, a practice that was common from the first half of the 17th century until the end of the industrial era. It was only with the advent of industrialization that the notion of "landscape" appeared. It was characterized by ideas of a mechanical landscape and in the broader sense, a mechanical worldview. As early as the first half of the 17th century, René Descartes formulated the basic idea: "We manufacture clocks, artificial fountains, mills and similar machinery, which - even though they are made by hand-are nevertheless capable of moving by themselves ... I see no difference between machines that are made by craftsmen and bodies assembled by nature alone." [10] This represented a radical break from the organic and spiritual models of the thought patterns of the Middle Ages: "For Descartes, the material universe was a machine, and nothing but a machine. In matter, there was neither a sense nor life, nor spirituality. The mechanical laws of nature work, and everything in the world of matter could, in terms of the arrangement and motion of its parts, be explained. This mechanical picture of nature became the dominant paradigm of the natural sciences in the period following Descartes. It determined all ... theories about natural phenomena ..." [9]. Even today, this mechanical worldview determines perceptions of the landscape. The use of landscapes by industry in thousands of cities and regions throughout the world, over the past 200 years, has led to consequences that now amount to existential questions. Changes in the environment are not merely the national problems of individual states. This is evidenced by their impact on world peace. In July 2011, at the time of the German Presidency of the UN Security Council, a topic of discussion was the danger posed to international

\section{References}

1 Baják I, Bajnok, L, Százéves a magyar szerszámgépgyártás (Hungarian tool-making is 100 years old), Gépipari tudományos egyesület, 1972, p. 34

2 Banik-Schweitzer, Zur Bestimmung der Rolle Wiens als Industriestadt für die wirtschaftliche Enticklung der Habsburgermonarchie, In Industriestadt Wien, Die Durchsetzung der industriellen Machtposition in der Habsburgerresidenz, Vienna, 1983, p. 5-7.

3 Bencze G, Váci út, a magyar gépipar föutcája (Váci Street, the security by rising sea levels, by the associated changes in maritime boundaries (including even the complete disappearance of small island states), and by increasing desertification, coupled with migration problems and food shortages [26]. Increased awareness of this problem on a global scale can be followed by action at the regional level.

Köbánya, with its former brewery companies, exemplifies a one-time mono-industrial area. As such, it offers opportunities for the study, documentation and differentiated description of a regional industrialization pattern. The knowledge gained can be used to identify and clarify relationships, which can help to ensure the sustainable utilization of similar areas (e.g. emerging industrial areas in China, India and Brazil) in line with human needs. In this process, the minimum task is to detoxify contaminated industrial landscapes and integrate the cultural aspects of the industrial age into the future design of the city or region [22]. The research results could also serve as a basis for the far-sighted regional planning management of future industrial estates, ensuring a balance between quantity and quality [13]. Comprehensive conceptual work on environmental issues in urban areas might reveal long-term problems associated with industrial and commercial activity. Such knowledge could be used in the future to avoid similar problems [23]. Solving this task is difficult, owing to the lack of a reliable vocabulary for the reconstruction of landscapes. The absence of a linguistic base makes it difficult to gain acceptance of sustainable concepts in society and promote an exchange of views among the various disciplines.

\section{Summary}

In the first half of the 19th century, breweries emitted major impulses for the industrial development of Pest-Buda. The location in an undeveloped landscape, coupled with designs reflecting functionality, was the starting point for a technicist architecture that became typical in the subsequent course of industrial architectural development. Köbánya, with its former brewery companies, exemplifies a one-time mono-industrial area. As such, it offers opportunities for the study, documentation and differentiated description of a regional industrialization pattern. The knowledge gained could be used to facilitate the sustainable utilization of similar areas (e.g. emerging industrial areas in China, India and Brazil) in line with human needs. 
brewing), Manuscript, Dokument aus dem Museum der Brauerei Dreher, Dok.-Nr. ST.I.o3oo, p. 129

7 Borsodi-Bevillág, Söripar története összállitása (History of beerbrewing), Manuscript, 1993, Dokument aus dem Museum der Brauerei Dreher, Dok.-Nr. ST.I.o3oo, p. 130

8 Borsodi-Bevillág, Söripar története összállitása (History of beerbrewing), Manuscript, 1993, Dokument aus dem Museum der Brauerei Dreher, Dok.-Nr. ST.I.o3oo, p. 132

9 Capra F, Wendezeit-Bausteine für ein neues Weltbild. Munich, 2004, p. 17

10 Descartes R, Discours de la méthode pour bien conduire sa raison et chercher la vérité dans les sciences. Paris, 1637

11 Fremlinger R, Tilly R, Industrialisierung und Raum. Stuttgart, 1979, p. 9

12 Frisnyák Zs, Közlekedési folyosók és városi térszerkezet Budapesten (Transport corridors and urban planning in Budapest), In Bécs-Budapest. Müszaki haladás és városfejlődés a 19. században. Budapest and Vienna, 2005

13 Jockers M, Industrie und Städtebau, In Deutsches Architektenblatt 31991.

14 Lukács J, A sörgyártás feljödése Köbányán (Development of brewing in Köbánya), Printed manuscript, Dokument aus dem Museum der Brauerei Dreher. Dok.-Nr. Sz.I.100, pp. 11-13

15 Németh J, A Technika és mérnökség magyarórszági története (History of technology and engineering in Hungary), Mủegyetemi Kiadó, 1999

16 Statisztikai Évkönyv (Statistical Yearbook) 1944-1946 (in Hungarian and French), Hungarian Central Statistical Office, p. 12

17 Neuhofer M, Regionale Differenzierung der Industrialisierung in Oberösterreich. Linz, 1989, p. 1

18 Palócz A, Városrendezés Bécsben és Budapesten (Urban planning in Vienna and Budapest), Budapest, 1894
19 Pilsitz M, A korai funkcionalizmus, mint a budapesti gyárépületek tervezési elve (Early functionalism as a planning principle for Budapest factory buildings), Építés-Építészettudomány 41, no. 3/4 (2013) (to be published)

20 Pilsitz M, Determining Factors for the Architectural Development of Factory buildings in Budapest between 1860 and 1918, Periodica Polytechnica Architecture 42, no. 1 (2011): pp. 43-58 DOI 10.3311/ pp.ar.2011-1.05

21 Pilsitz M, 1805-1840 közötti pest-budai belvárosi sörfözdék-a funkcionális célépitészet kezdetei (The beginnings of functional architecture in the urban breweries of Pest-Buda between 1805 and 1840), In Historia Scientiarum 11 (2013), pp. 28-36.

22 Pilsitz M, Müemlék az ipari épitészetben (Historic buildings in industrial architecture), Építés-Építészettudomány 40, no. 1-2 (2012): pp. 97-112

23 Pilsitz M, Történelmi ipari épületek kutatása-keretfeltételek, módszerek és az IBA 2010 (Research on historical industrial buildings framework conditions, methods and the IBA 2010), In 16th Building Services, Mechanicel and Building Industry Days. Konferenciakötet, University of Debrecen, 2010, pp. 387-392.

24 Preisich G, Budapest városépitésének története, A Kiegyezéstöl a tanácsköztársaságig (The History of urban architecture in Budapest from the Compromise to the Republic of Councils), 1964, p. 54

25 Vámossy F, Az ipari épitészet fejlödése (The development of industrial architecture), Magyar Építőmüvészet 2 (1964): pp. 61-63

26 www.auswaertiges-amt.de (2013.03.07)

27 Zakariás G. S, Adatok Buda épitészetéhez a XIX. szászad első felében (Data on architecture in Buda in the first half of the 19th century), In Tanulmányok Budapest múltjából, XII. Kötet. 1957, pp. 279-283 